\title{
Experimental and CFD Analysis of Combustion in Diesel Engine for Various Ethanol-Diesel Blends
}

\author{
Sharath $\mathbf{P}^{1}$, Ajith $\mathbf{K}^{\mathbf{2}}$ \\ ${ }^{1}$ Assistant Professor, Department of Mechanical Engineering, Jawaharlal College of Engineering and Technology, Ottapalam \\ ${ }^{2}$ Assistant Professor, Department of Mechanical Engineering, Jawaharlal College of Engineering and Technology, Ottapalam
}

\begin{abstract}
Diesel engines are used widely around the globe as power plants for various purposes due to their excellent drivability and economy. But they are also the major contributors of air pollutants such as $\mathrm{CO}, \mathrm{NO}, \mathrm{PM}$ and other harmful compounds. At the same time the global fuel crises and increase in fuel prices have led us to the need of developing an alternate fuel that would give a solution to these problems. For about a decade researches and investigations were conducted on the use of ethanol-diesel blend as a fuel in diesel engines. Many proposals were made and few are commercially implemented. Many of the results comes to a conclusion that ethanoldiesel blend could solve the problems mentioned above. The aim of this project is to find the optimum ethanol-diesel blend that suits the diesel engines presently available in the market and could be used without much modification in the engine. With the help of various methods to find fuel properties, performance test on diesel engine for various fuel blends and software analysis the optimum blend is found out. The blend of fuel found out as the result of this project could be the fuel that drives the future.
\end{abstract}

Keywords: Ethanol-Diesel blend

\section{Introduction}

Ethanol is an attractive alternative fuel because it is a renewable bio-based resource and it is oxygenated, thereby providing the potential to reduce particulate emissions in compression-ignition engines. Ethanol is a renewable energy; it can be made from many raw materials such as sugar cane, molasses, cassava, waste biomass materials, sorghum, corn, barley, sugar beets, etc. by using already improved and demonstrated technologies. The dwindling fossil fuel sources and the increasing dependency on imported crude oil have led to a major interest for many countries in expanding the use of bioenergy.

In this project the properties and specifications of ethanol blended with dieselfuel are discussed. These factors include blend properties such as stability, viscosity and lubricity, safety and materials compatibility. The effect of the fuel on engine performance, durability and emissions is also considered.

\section{Problems Associated with Implementing Ethanol - Diesel Blend as Fuel in Diesel Engines and Methods to Overcome it}

The ethanol used in the tests was limited to essentially anhydrous ethanol because other kinds of ethanol are not soluble or have very limited solubility in the vast majority of diesel fuels. The solubility of ethanol in diesel fuel is dependent on the hydrocarbon composition, wax content and ambient temperature of the diesel fuel. This solubility is also dependent on the water content of the blend fuels. Ethanol solubility in diesel is affected mainly by two factors, temperature and water content of the blend. At warm ambient temperatures dry ethanol blends readily with diesel fuel. However, below about $10^{\circ} \mathrm{C}$ the two fuels separate, a temperature limit that is easily exceeded in many parts of the world for a large portion of the year. Prevention of this separation can be accomplished in two ways: by adding an emulsifier which acts to suspend small droplets of ethanol within the diesel fuel, or by adding a co-solvent that acts as a bridging agent through molecular compatibility and bonding to produce a homogeneous blend.

The major problem associated with use of alcohol in diesel engine is, the limited miscibility at lower temperature and the required minor variations in fuel delivery systems restrict the use of ethanol in diesel. One of the effective approaches is adding oxygenated fuel to solve the above problem without any modification of the engine. The selection of oxygenated fuels is based on economic viability, toxicity and fuel blending properties. Ethanol (97 to 99\%) is highly soluble in diesel fuel at contents of approximately $0-20 \%$ and $80-100 \%$ within this region of miscibility; we observe cloudiness in the mixture followed by separation. When the water content of ethanol exceeded $1 \%$ the occurrence of this phenomena can be prevented by using additives.

When the ethanol content is more than $45 \%$, misfire is normally observed under some conditions, because the ignition delay is pro-longed due to the low cetane number of ethanol in the blend fuels. The ignition occurs wellafter the top dead center (TDC), especially at high speed.

With the ethanol-diesel blend the engine starts without any problem and it runs smooth, but with the increase in ethanol content upto $50 \%$ engine noise develops.

Lower cetane numbers means longer ignition delays, allowing more time for fuel to vaporize before combustion starts. Initial burn rates are higher causing more heat release at constant volume, which is a more efficient conversion process of heat to work.

The flammability characteristics of ethanol-diesel blends were more like those of ethanol than diesel fuel with headspace vapors of these blends being flammable within storage tanks at approximately $12^{\circ}-42^{0} \mathrm{C}$ compared to diesel fuel at $64^{\circ} \mathrm{C}$. Temperatures of fuel in the tank of diesel-fueled vehicles 


\section{International Journal of Science and Research (IJSR) \\ ISSN (Online): 2319-7064 \\ Index Copernicus Value (2013): 6.14 | Impact Factor (2015): 6.391}

are raised because of fuel recirculation needed to cool the fuel injection system. Temperatures as high as $93^{\circ} \mathrm{C}$ may be expected. A key hazard of the higher flammability limits is ignition of the plume of vapor leaving the tank during refueling as a result of external sparks, static discharge or smoking materials.

\section{Experimental Analysis}

The specification of the selected diesel engine is shown in Table 1. Single cylinder four-stroke watercooled diesel engine running at constant speed of $1500 \mathrm{rpm}$ was used for this work. The engine consists of an electric loading arrangement for measuring net load and fuel consumption.

Table 1: Engine Specifications

\begin{tabular}{|c|c|}
\hline Bore Diameter & $80 \mathrm{~mm}$ \\
\hline Stroke Length & $110 \mathrm{~mm}$ \\
\hline No. of Strokes & 4 \\
\hline No. of Cylinders & 1 \\
\hline Rated Power & $5 \mathrm{hp}(3.73 \mathrm{KW})$ \\
\hline Rated Speed & $1500 \mathrm{rpm}$ \\
\hline Type of Cooling & Water Cooled \\
\hline Type of Loading & Electrical Type \\
\hline Alternator Efficiency & $80 \%$ \\
\hline Energy Meter Constant & $300 \mathrm{rev} / \mathrm{kwhr}$ \\
\hline
\end{tabular}

\section{a) Properties of the blended fuel used}

\section{1) Calorific value}

The calorific value of any substance can be found using a bomb calorimeter.

\section{2) Density}

Density of the fuel blend can be found out by using a measuring flask and weighing machine.

Table 2: Density and Calorific Value Of Various Blends

\begin{tabular}{|c|c|c|}
\hline Fuel & Density $\left(\mathrm{kg} / \mathrm{m}^{3}\right)$ & Calorific Value $(\mathrm{kJ} / \mathrm{kg})$ \\
\hline DIESEL & 820 & 44514 \\
\hline E5 & 818.99 & 43631 \\
\hline E10 & 811.60 & 43192 \\
\hline E15 & 806.3 & 42744 \\
\hline E20 & 803.4 & 41874 \\
\hline
\end{tabular}

\section{b) Performance test}

Performance test is carried out in a single cylinder four stroke diesel engine by using the diesel fuel and ethanol blends such as E5, E10, E15, and E20.

\section{1) Specific fuel consumption}

The variation of brake specific fuel consumption with brake power is shown in table 4.1. It is reveals that as the load increases the fuel consumption decrease. At full load condition specific fuel consumption obtained are 0.336 $\mathrm{kg} / \mathrm{kwhr}, 0.316 \mathrm{~kg} / \mathrm{kwhr}, 0.301 \mathrm{~kg} / \mathrm{kwhr}, 0.287 \mathrm{~kg} / \mathrm{kwhr}$, $0.282 \mathrm{~kg} / \mathrm{kwhr}$ for fuels of diesel, E5, E10, E15 and E20 respectively. Brake specific fuel consumption is decreased with the blends when compared to diesel.
Table 3: SFC for Various Blends At Various Loads

\begin{tabular}{|c|c|c|c|c|}
\hline DIESEL & E5 & E10 & E15 & E20 \\
\hline 1.02 & 0.880 & 0.867 & 0.850 & 0.890 \\
\hline 0.504 & 0.470 & 0.425 & 0.413 & 0.421 \\
\hline 0.439 & 0.354 & 0.349 & 0.337 & 0.357 \\
\hline 0.357 & 0.306 & 0.303 & 0.299 & 0.306 \\
\hline 0.336 & 0.316 & 0.301 & 0.287 & 0.282 \\
\hline
\end{tabular}

\section{2) BrakeThermal Efficiency (BTE)}

The variation of brake thermal efficiency with brake power is shown in table 4.2. From the plot it is observed that as the load increases the brake thermal efficiency increases. At full load condition the brake thermal efficiency obtained are $24.08 \%, 26.11 \%, 27.69 \%, 29.25 \%$ and $30.46 \%$ for fuels of diesel, E5, E10, E15 and E20 respectively.

Table 4: BTE for Various Blends At Various Loads

\begin{tabular}{|c|c|c|c|c|}
\hline DIESEL & E5 & E10 & E15 & E20 \\
\hline 0 & 0 & 0 & 0 & 0 \\
\hline 7.96 & 9.37 & 9.61 & 9.90 & 9.65 \\
\hline 16.03 & 17.53 & 19.57 & 20.36 & 20.41 \\
\hline 18.45 & 23.34 & 23.82 & 24.98 & 24.06 \\
\hline 22.71 & 27.00 & 27.49 & 28.16 & 28.07 \\
\hline 24.08 & 26.11 & 27.69 & 29.24 & 30.46 \\
\hline
\end{tabular}

\section{3) Indicated Thermal Efficiency (ITE)}

The variation of indicated thermal efficiency with brake power is shown in table 4.3. It reveals that as the load increases the indicated thermal efficiency increases. At full load condition the indicated Thermal efficiency obtained are $35.90 \%, 33.92 \%, 36.02 \%, 37.89 \%$ and $39.36 \%$ for fuels of diesel, E5, E10, E15 and E20 respectively.

Table 5: ITE for Various Blends At Various Loads

\begin{tabular}{|c|c|c|c|c|}
\hline DIESEL & E5 & E10 & E15 & E20 \\
\hline 20.83 & 13.82 & 14.53 & 14.55 & 14.68 \\
\hline 26.59 & 22.09 & 22.79 & 23.42 & 23.16 \\
\hline 32.06 & 28.18 & 30.91 & 32.23 & 32.34 \\
\hline 33.48 & 33.27 & 34.17 & 35.70 & 34.54 \\
\hline 35.18 & 35.53 & 36.32 & 37.25 & 37.22 \\
\hline 35.90 & 33.92 & 36.02 & 37.89 & 39.36 \\
\hline
\end{tabular}

4) Mechanical Efficiency (ME)

This is the rating that shows how much of the power developed by the expansion of the gases in the cylinder is actuallydelivered as useful power. The factor which has the greatest effect on mechanical efficiency is friction within the engine. The friction between moving parts in an engine remains practically constant throughout the engine's speed range. Therefore, the mechanical efficiency of an engine will be highest when the engine is running at the speed at which maximum bhp is developed. The variation of mechanical efficiency with brake power is shown in table 4.4. It reveals that as the load increases the mechanical efficiency increases. At full load condition the brake thermal efficiency obtained are $67.06 \%, 76.98 \%, 76.88 \%, 77.18 \%$ and $77.38 \%$ for fuels of diesel, E5, E10, E15 and E20 respectively. 


\section{International Journal of Science and Research (IJSR) \\ ISSN (Online): 2319-7064}

Index Copernicus Value (2013): 6.14 | Impact Factor (2015): 6.391

Table 6: ME For Various Blends At Variousloads

\begin{tabular}{|c|c|c|c|c|}
\hline DIESEL & E5 & E10 & E15 & E20 \\
\hline 0 & 0 & 0 & 0 & 0 \\
\hline 29.94 & 42.51 & 42.16 & 42.29 & 41.66 \\
\hline 50.01 & 62.18 & 63.31 & 63.18 & 63.11 \\
\hline 55.1 & 70.14 & 69.73 & 69.98 & 69.65 \\
\hline 64.56 & 75.99 & 75.70 & 75.6 & 75.41 \\
\hline 67.06 & 76.98 & 76.88 & 77.18 & 77.38 \\
\hline
\end{tabular}

c) Performance graphs
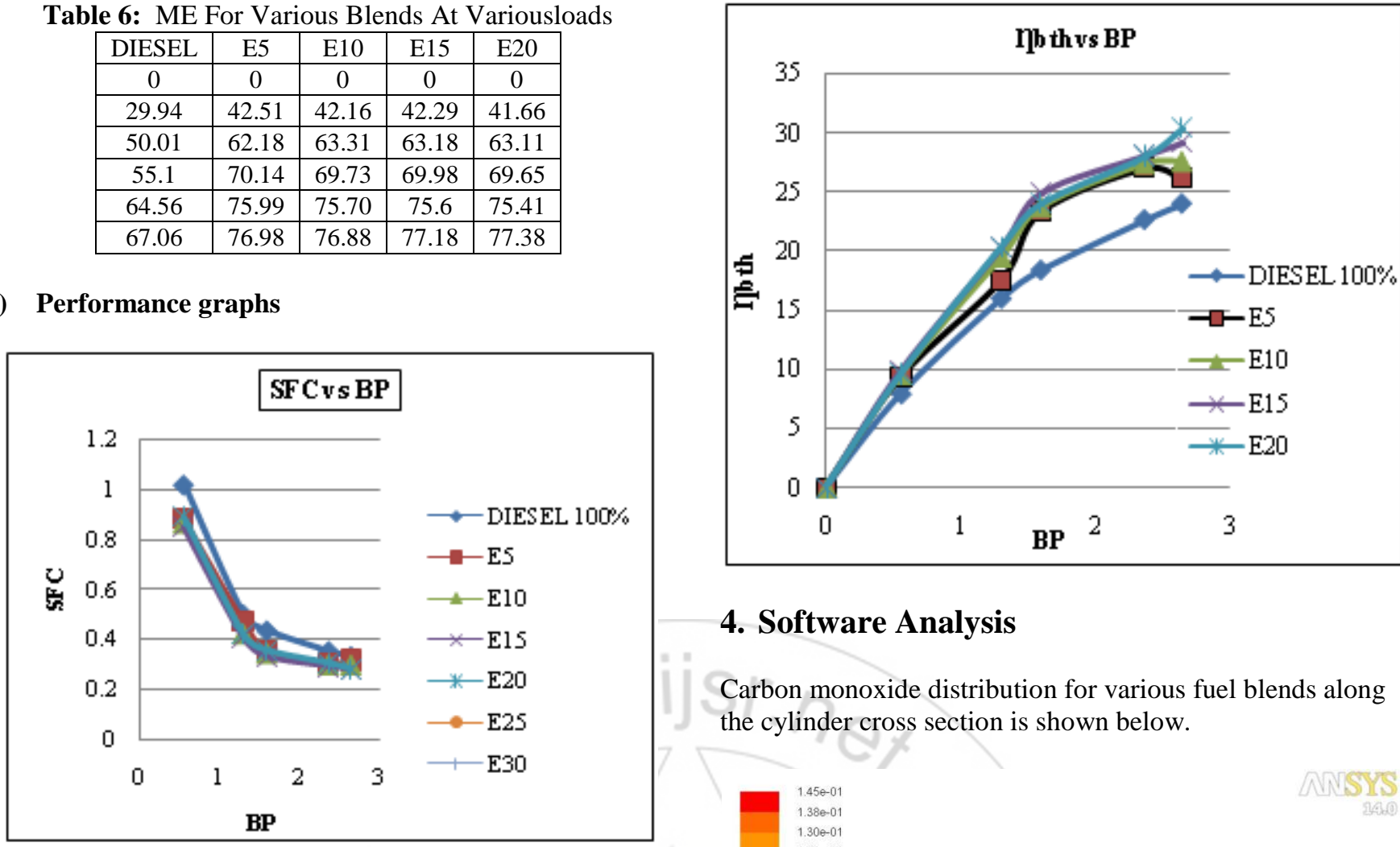

\section{Software Analysis}

Carbon monoxide distribution for various fuel blends along the cylinder cross section is shown below.

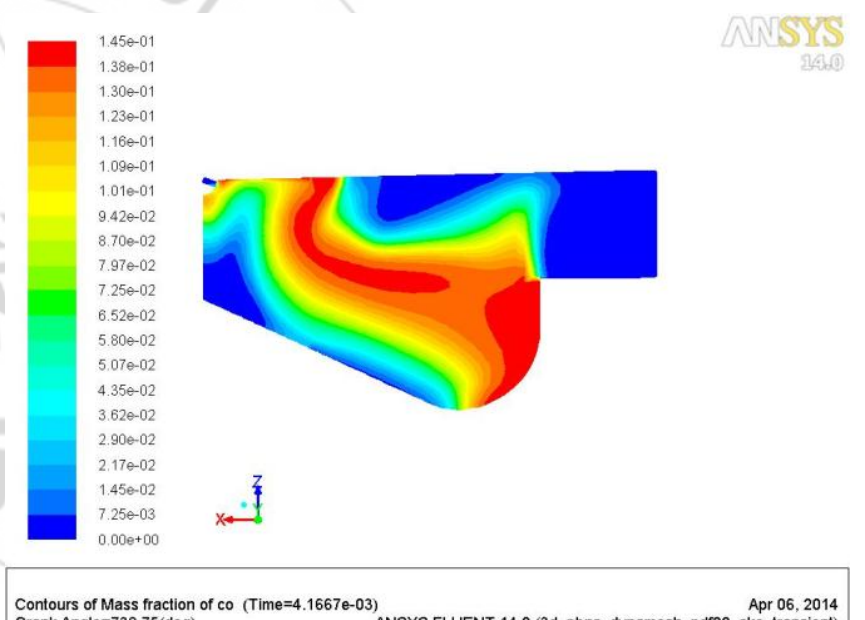

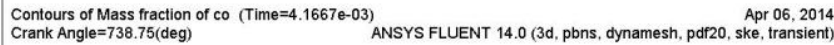
Figure 1: CO distribution when diesel is used
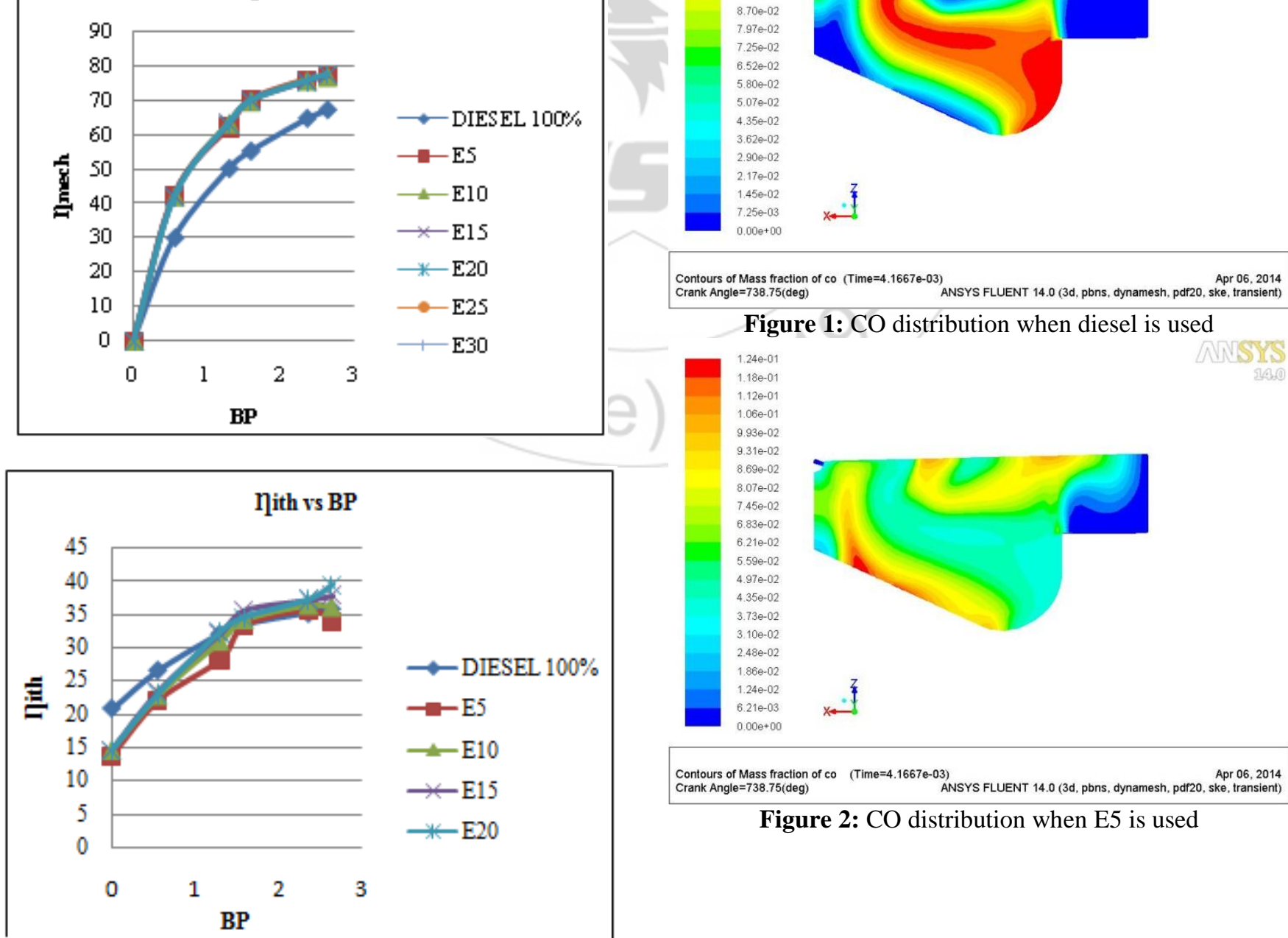

Figure 2: $\mathrm{CO}$ distribution when E5 is used

\section{Volume 5 Issue 5, May 2016}




\section{International Journal of Science and Research (IJSR) \\ ISSN (Online): 2319-7064}

Index Copernicus Value (2013): 6.14 | Impact Factor (2015): 6.391

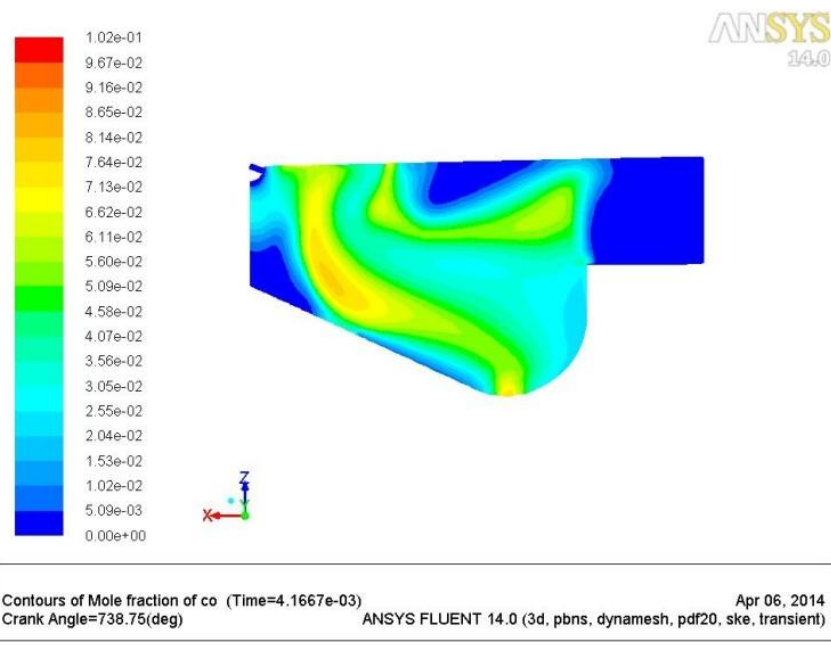

Figure 3: $\mathrm{CO}$ distribution when E10 is used

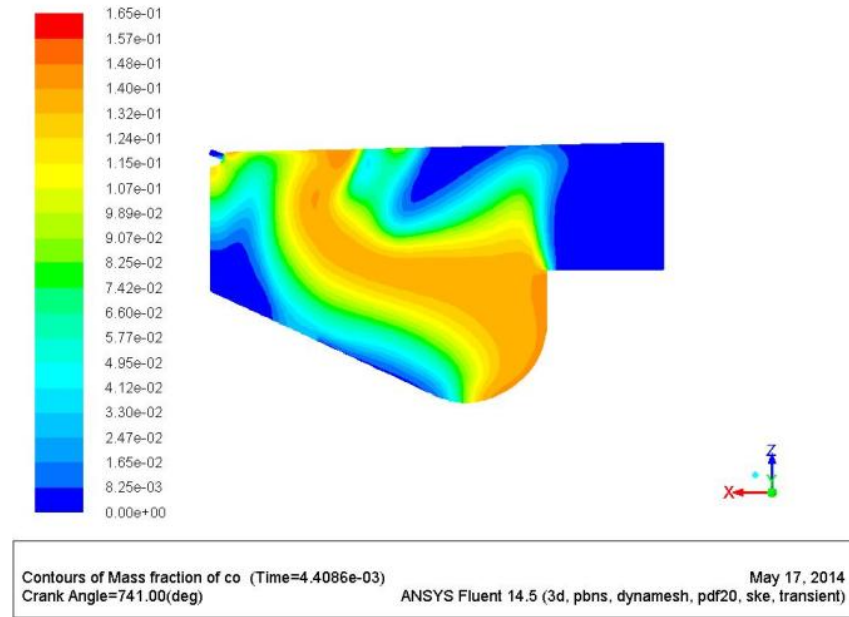

Figure 4: CO distribution when E20 is used

Pressure distribution for various fuel blends along the cylinder cross section is shown below.

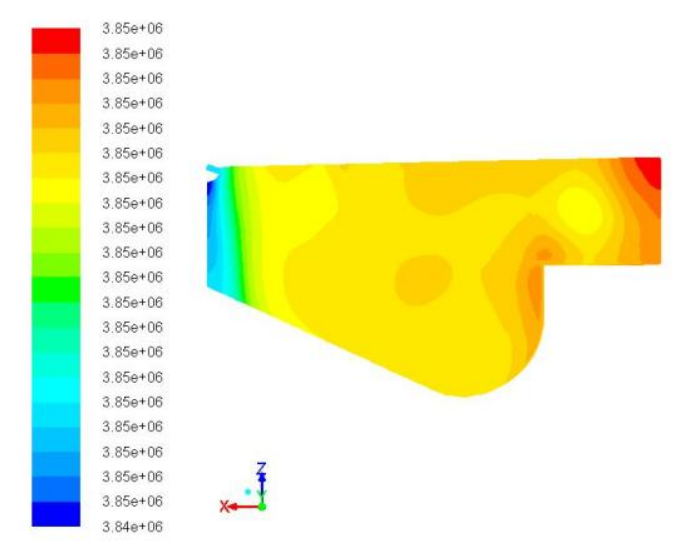

Contours of Static Pressure (pascal) (Time $=4.1667 \mathrm{e}-03$ ) Crank Angle $=738.75$ (deg)

Figure 5: Pressure distribution when diesel is used

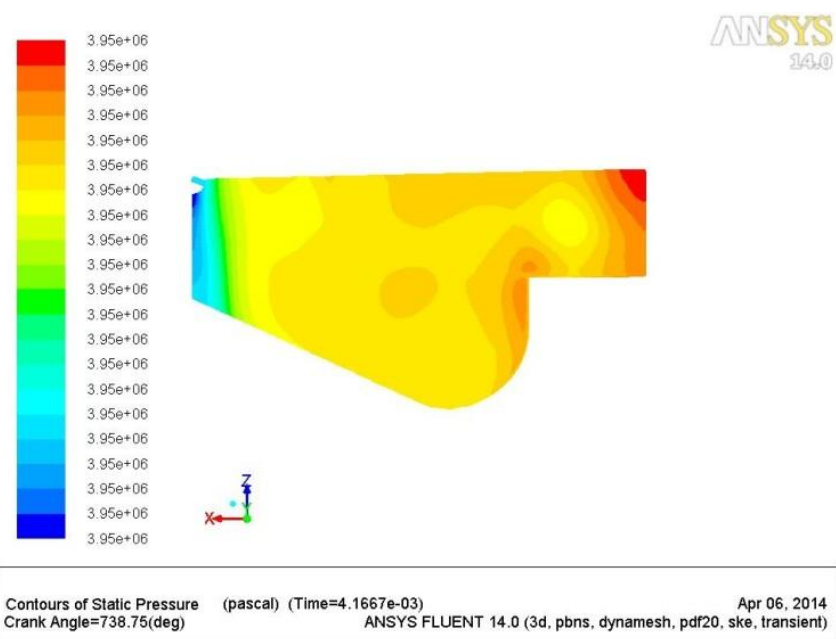

Figure 6: Pressure distribution when E5 is used

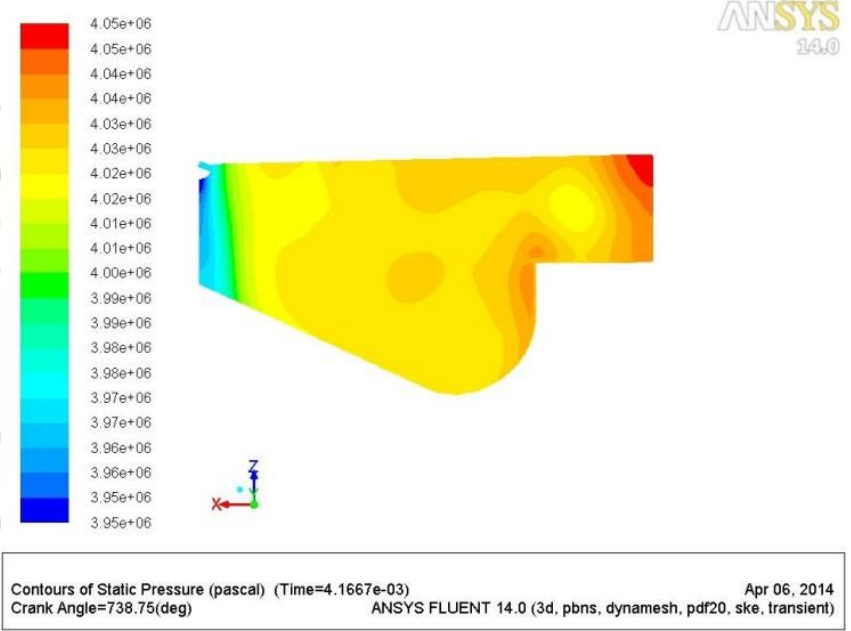

Figure 7: Pressure distribution when E10 is used

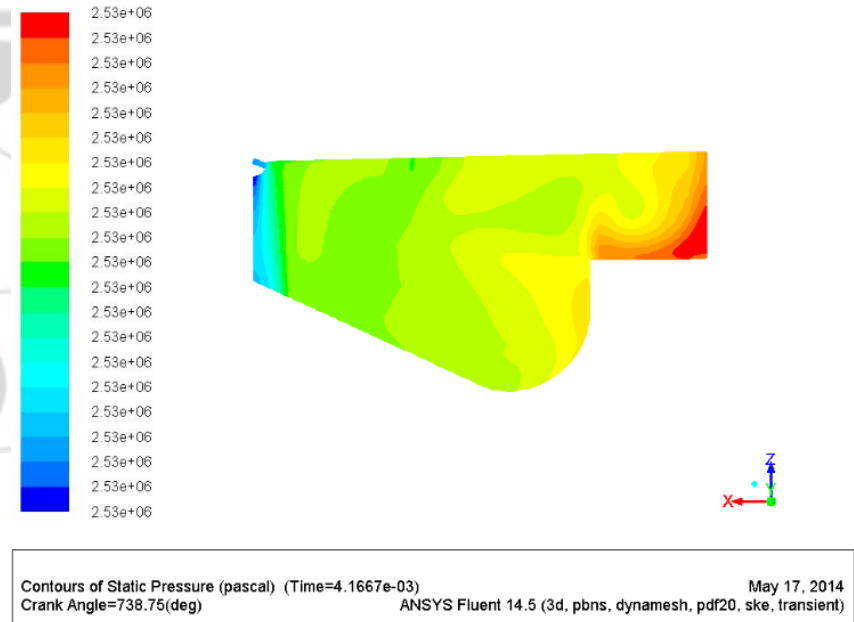

Figure 8: Pressure distribution when E10 is used

Temperature distribution for various fuel blends along the cylinder cross section is shown below. 


\section{International Journal of Science and Research (IJSR) \\ ISSN (Online): 2319-7064}

Index Copernicus Value (2013): 6.14 | Impact Factor (2015): 6.391

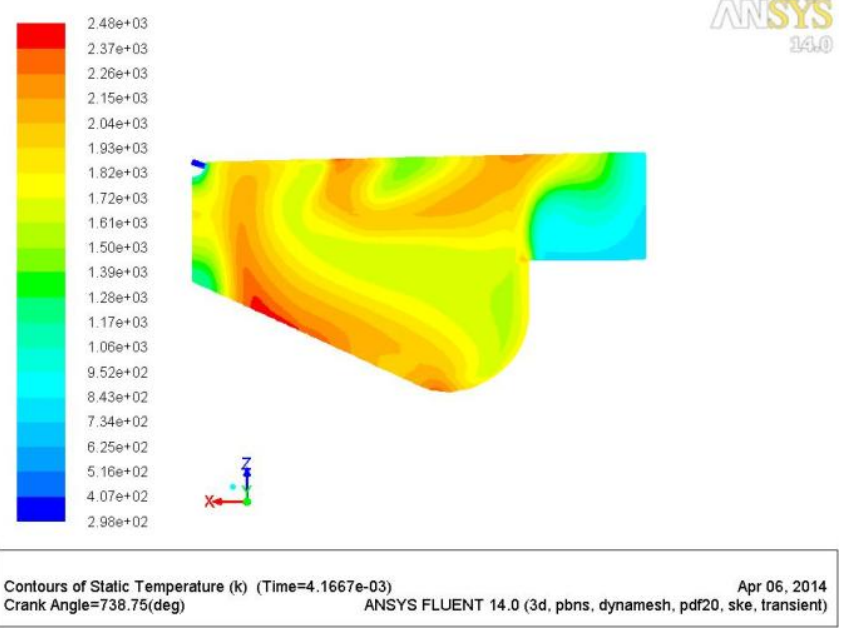

Figure 9: Temperaturedistribution when Diesel is Used

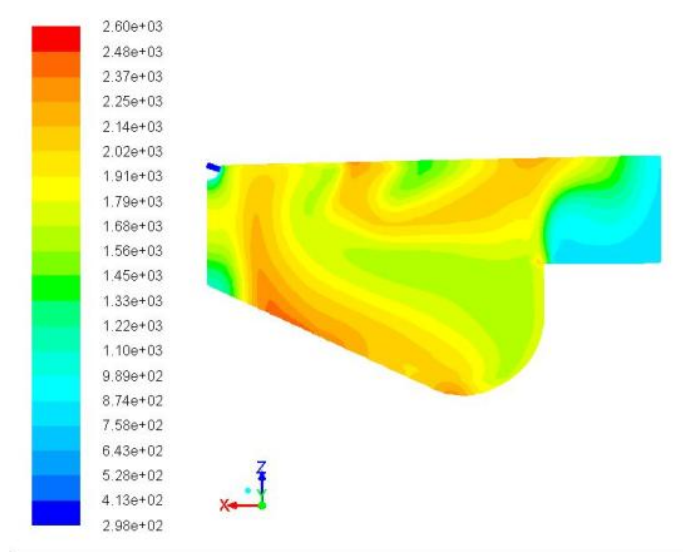

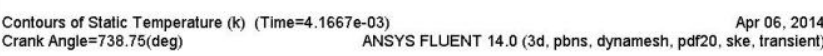

Figure 10: Temperature distribution when E5 is used

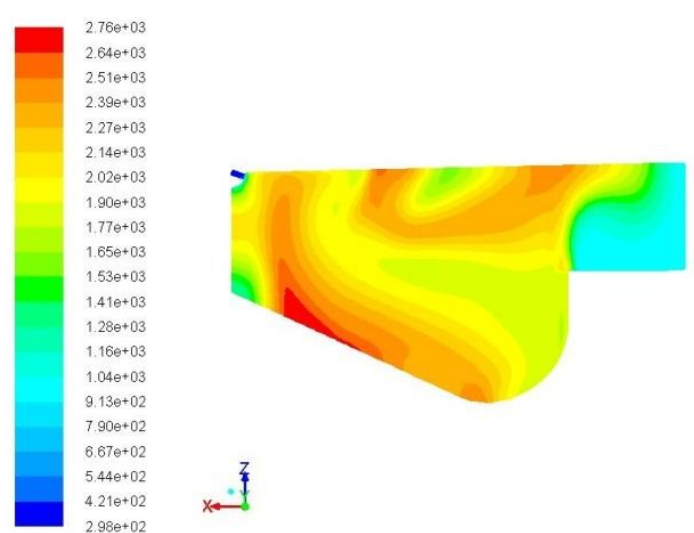

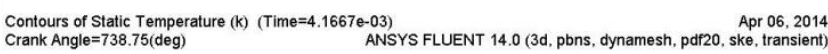

Figure 11: Temperature distribution when E10 is used

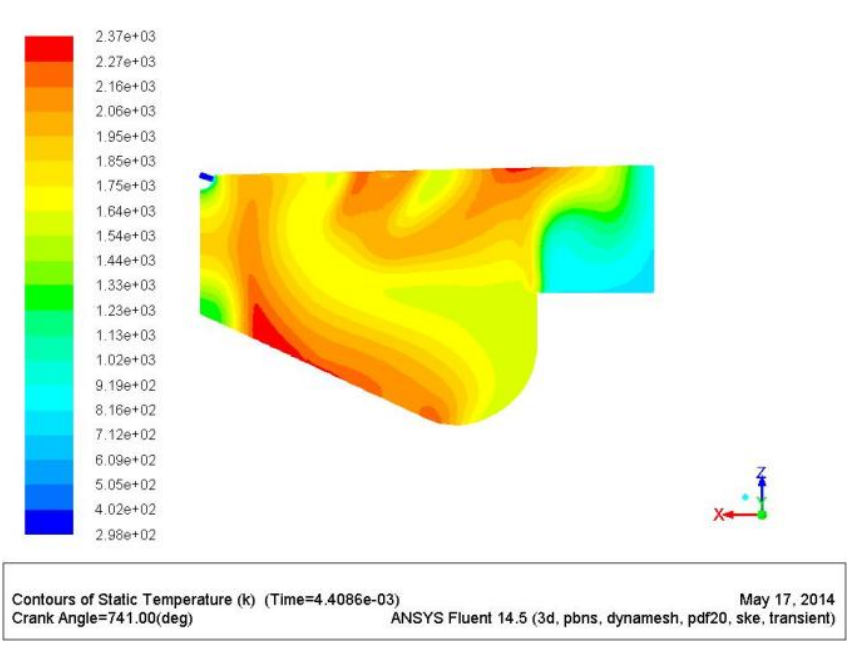

Figure 12: Temperature distribution when E20 is used

$\mathrm{NO}_{\mathrm{x}}$ distribution for various fuel blends along the cylinder cross section is shown below.

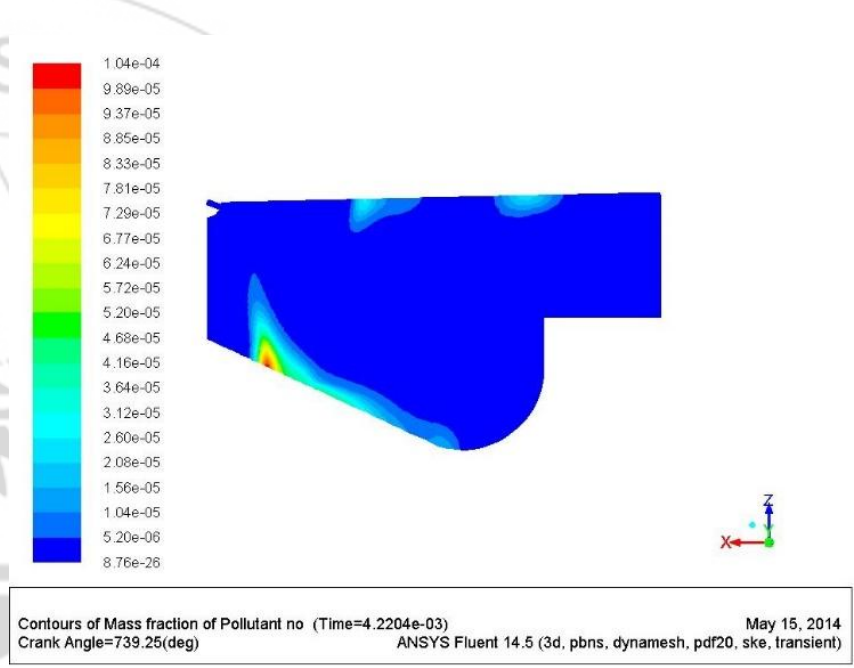

Figure 13: $\mathrm{NO}_{\mathrm{x}}$ distribution when diesel is used

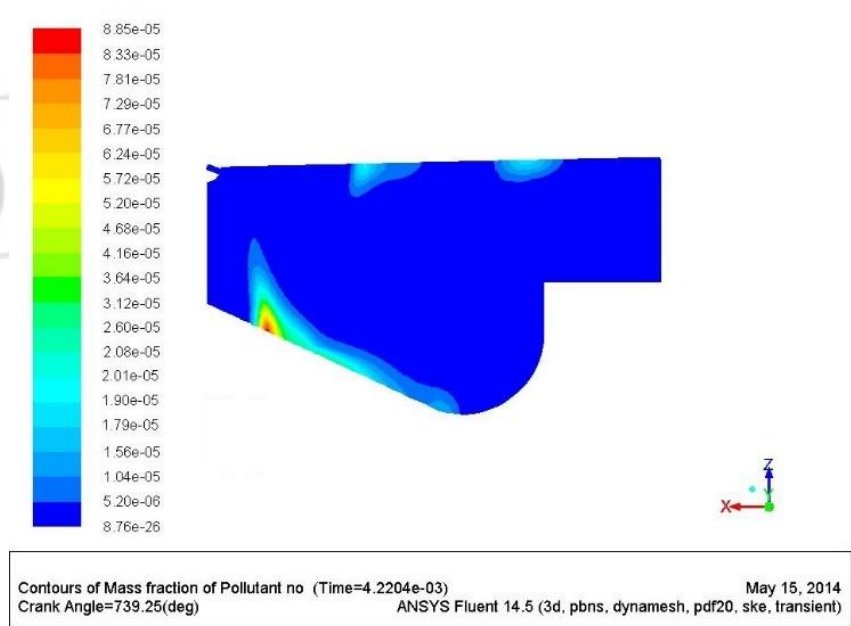

Figure 14: $\mathrm{NO}_{\mathrm{x}}$ distribution when E5 is used 


\section{International Journal of Science and Research (IJSR) \\ ISSN (Online): 2319-7064}

Index Copernicus Value (2013): 6.14 | Impact Factor (2015): 6.391

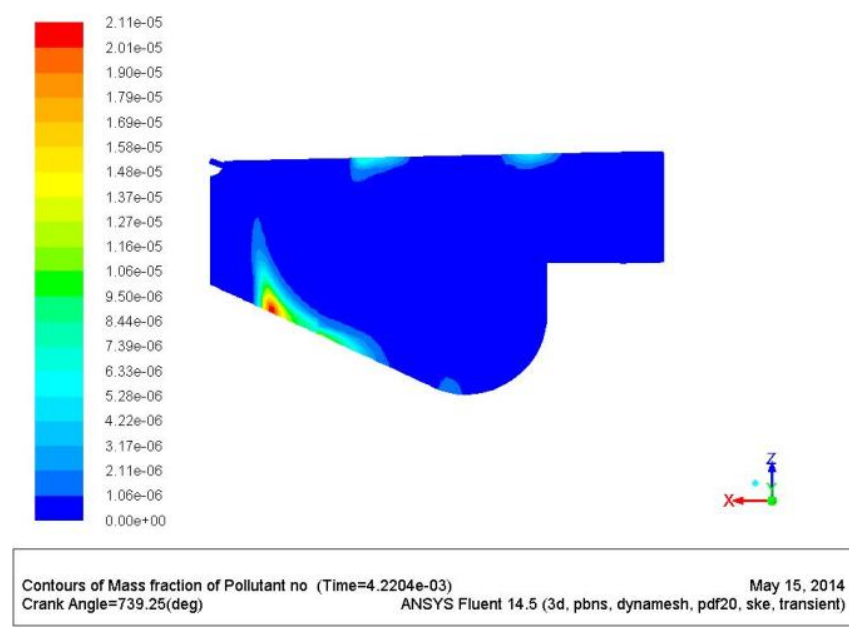

Figure 15: $\mathrm{NO}_{\mathrm{x}}$ distribution when $\mathrm{E} 10$ is used
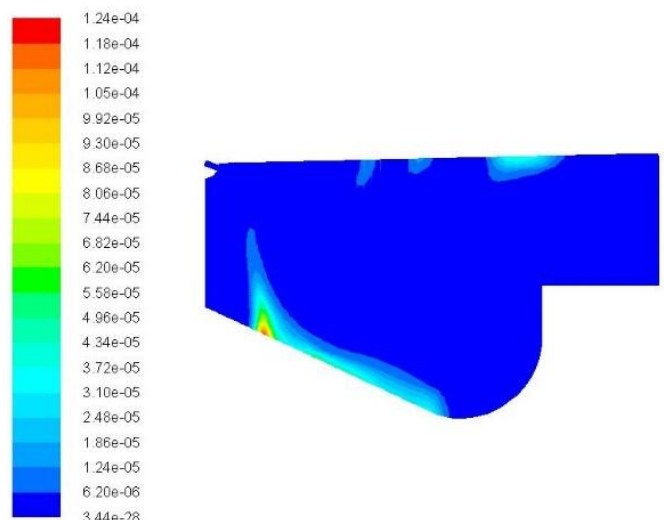

Contours of Mass fraction of Pollutant no (Time $=4.4624 \mathrm{e}-03$ ) Crank Angle=741.50(deg)

Figure 16: $\mathrm{NO}_{\mathrm{x}}$ distribution when $\mathrm{E} 20$ is used

\section{Conclusion}

The conclusions derived from present experimental investigations to evaluate performance characteristics on four stroke single cylinder diesel engine fueled with diesel Ethanol blends are summarized as follows. Brake thermal efficiency increased with all blends when compared to the conventional diesel fuel. The Brakespecific fuel consumption is decreased with the blends when compared to diesel. From the above analysis the blend E20 shows the better performance compared to other blends. From the present study the relative density of all the blends were found to be lower than that of diesel fuel alone. The relative density was dependent on temperature. Calorific values of the blends were lower than that of diesel but the deviation from the calorific value of diesel is approximately less than $5 \%$, which is within acceptable range. In general, blends containing 5, 10, 15 and $20 \%$ ethanol have very close fuel properties compared to diesel fuel. From the above analysis it is clear that the efficiency of the diesel engine is increased with increasing the percentage of ethanol.

From the CFD analysis we can see that, as the ethanol content is increasing in the fuel $\mathrm{CO}$ level is decreasing after combustion of the fuel. There is not much variation in pressure and temperature levels as the ethanol content is increasing. From the NOx analysis we can see that its content is decreasing with the increase of ethanol content in the fuel.

These analysis help us to confirm that diesel oxygenated with ethanol does not adversely affect engine wear compared to diesel fuel. It is accepted that the addition of ethanol to diesel fuel will have a beneficial effect in reducing the PM emissions at least.

\section{References}

[1] Ahmed, I. (2001). Oxygenated Diesel: Emissions and Performance Characteristics of Ethanol- Diesel Blends in CI Engines. Society of Automotive Engineers, 200101-2475.

[2] Ajav, E.A., Akingbehin, O.A. "A study of some fuel properties of local ethanol blended with diesel fuel". March 2002.

[3] Battelle. "Flammability limits for ethanol-diesel blends". Growmark, Inc. September 1998.

[4] Eric Kurtz, Douglas Kuhel, James E. Anderson and Sherry A. Mueller, "A Comparison of Combustion and Emissions of Diesel Fuels and Oxygenated Fuels in a Modern DI Diesel Engine." Department of Energy, under special project number DE-FC26-07NT43278

[5] Suppes, G. J. (2000) Past mistakes and future opportunities of ethanol in diesel. 9 thBioEnergy Conference, New York. October 2000.

[6] Pang, X., Shi, X. et al. (2006). Characteristics of carbonyl compounds emission from a diesel-engine using biodiesel-ethanol-diesel as fuel. Atmospheric Environment 40(2006) 7057-7065. Science Direct online.

[7] Waterland, L. et al. (2003). Safety and Performance Assessment of Ethanol/Diesel Blends (E-diesel). September 2003. Report NREL/SR-540-34817.

[8] Reardon, B. (2001). Ethanol-Blended Diesel Fuel Passes DemandingThree-YearTrial. spinotew1.commerce.state.il.us

[9] Reynolds, R. (2002). Fuel specifications and fuel property issues And their potential impact on the use of ethanol as a transportation fuel. Oak Ridge National Laboratory Ethanol Project. Subcontract No. 4500010570 . 